research have been completed. The most that can be expected is some means of preventing snap and ex parte decisions in which conflicting claims and longterm interests are ignored. Adjustment of such claims and of short- and long-term interests must of necessity take place at a high level, but this does not imply of necessity a super-planning authority. The Ministry of Local Government and Planning is clearly capable of bringing into the discussions the reasonableness which makes co-operation and adjust. ment possible, and to that extent has justified its establishment though not necessarily the full extent of its organization. On that side there is room for much clearer thinking; but on the record here presented, the Ministry is entitled to claim the support of all who are concerned to see that the use of the land of Britain shall be determined on the basis of the fullest possible factual knowledge and on the due consideration of all the conflicting interests involved from a national and not from a purely sectional point of view.

\section{TIME AND CLIMATE}

Dating the Past

An Introduction to Geochronology. By Prof. Frederick E. Zeuner. Second edition, revised and enlarged. Pp. xviii $+474+24$ plates. (London : Methuen and Co., Ltd., 1950.) 30s. net.

THIS work is a second edition of a book first published in 1945. It opens with a discussion of the methods of dating by tree rings and varves, and their use in establishing a chronology of Neolithic and post-Glacial times. This is followed by a discussion of the correlation and climatic changes of the Old Stone Age. The last eighty pages describe the time-scale for the whole geological column before the Pleistocene, as derived from radioactive considerations, and discuss the rate of evolution. The subject therefore includes diverse fields of the greatest difficulty and complexity. Its proper discussion demands a critical consideration of the whole of archæology and prehistory, a balanced judgment on the most delicate points of statistical theory and some knowledge of astronomy, meteorology and nuclear physics. To say that the author does not possess the necessary knowledge is not a criticism: no one does, least of all the present writer. To pick holes is easy ; there are statements that "make one gasp and stretch one's eyes", as, for example, where it is said on page 16, "of 96 sun spots no fewer than 63 have periods between 9.9 and 11.9 years". Such absurdities are probably inevitable in so long and diverse an argument and do not touch the real purpose of the book.

The main theme is that the Croll-Ball-Milankovitch theory of the astronomical cause of ice ages gives an alternation of cool and warm periods that conforms to the facts of archæology. I must confess that I remain unconvinced. An enormous and intricate structure of fact and surmise is presented that at many points fits well with the calculated curves giving the variation of the heat arriving from the sun at the surface of the earth. It is rash for an amateur in these matters to question such a performance; but awkward doubts occur. Why is America dismissed in one page although, "In North
America, Pleistocene chronology is, of course, highly developed" ? Can it be because it gives little evidence in support of Milankovitch? Is the evidence for three phases of the last glaciation derived from the three buried channels near the mouth of the Thames convincing ? There is a channel for each phase, and in a table it looks admirable until one remembers that there are dozens of other buried channels in southern England that are not mentioned.

It may with some justice be argued that a dubious or incorrect principle is better than none, and that, right or wrong, Prof. F. E. Zeuner does provide a framework on which to hang the facts, and does introduce some order into the chaos of prehistory. If the framework is, in fact, wrong, the quickest way to demonstrate it is to hang facts on it until they patently will not fit. In the meantime, it would be difficult to suggest an alternative as detailed that would fit at all.

I think it is impossible for anyone used to the firm ground of physical science, or even to the penumbra of doubt that usually accompanies a geological fact, to read any discussion of prehistoric chronology without a profound feeling of distrust. The mind revolts at such fare. Why should one believe Prof. A. rather than Prof. B. or Prof. Z. ? What are the criteria? What is fact and what is wishful thinking? If one is told bluntly that Korn has observed a "sunspot cycle" of 11.5 years in the thickness of the varves in the pre-Cambrian Nama beds in South-West Africa, does it mean that the matter is beyond reasonable doubt? After looking at Korn's paper, I am very doubtful of the existence of any real periodicity, and certain that the point has not been established. The correlation of varve and tree-ring sections and the extraction of period. icities from them are statistical questions involving series the terms of which are not independent. It is remarkable that the great developments in the theory of such series in the last ten years have not been applied in this field. Arguments based on the assumption that the terms must either be independent or be governed by 'periods' can never be convincing. There seems to be a firmly planted instinct in the human mind that wishes to find periods in autocorrelated series, and there is no subject in which there is a greater danger of error. The weakness of Prof. Zeuner's argument in this respect is not to be laid at his door; the subject has just not been developed in a satisfactory manner. In some matters he shows more caution than his predecessors; in particular, he expresses a well-founded disbelief in the teleconnexion of varve series.

In spite of all these doubts and uncertainties, Prof. Zeuner's book does serve a most valuable purpose. It brings together in a coherent way a great body of knowledge and sets it out in such a manner that everyone can see how defective our understanding of it is. The next step in the solution of the difficulties probably lies with the physicist, the chemist and the oceanographer, and for them an easily digested summary such as this is invaluable. It is likely that in the next ten years work on radioactive carbon, on the distribution of isotopes and on ionium in ocean cores will enable us to obtain a knowledge of the changes of temperature in the past and of their dates. It may well be that in his next edition Prof. Zeuner will be able to give some of his dates and correlations as facts. $\mathrm{He}$ could then with confidence reverse many of his arguments and use the dates to support his interpretation of the facts. E. C. Bullard 